\title{
Truth, Inquiry and the Settlement of Belief: Pragmatist Accounts
}

\section{Verdad, investigación y establecimiento de creencias: explicaciones pragmatistas}

\author{
Paniel Reyes Cárdenas \\ Universidad Popular del Estado de Puebla, México \\ panielosberto.reyes@upaep.mx \\ Recibido: 21/12/2016 • Aceptado: 02/02/2017
}

\begin{abstract}
Pragmatism is a doctrine that enlists several authors holding different, apparently irreconcilable positions. Pragmatist philosophers often cast views that might seem clearly the opposite slogan of their other pragmatist peers who ascribe themselves this name. Pragmatists like Richard Rorty, for example, believe that fallibilism forbids us to accept that truth can be the end of inquiry. Rorty complains about Peirce's «methodolatry» and pushes forward for an account free of metaphysical commitments with theories of truth. Against this view, other Peircean pragmatists, such as Cheryl Misak and Christopher Hookway, offer an understanding of the sense in which truth can be an end of inquiry and of the way in which belief is settled rationally.
\end{abstract}

\section{Resumen}

El pragmatismo es una doctrina que reúne a varios autores que sostienen posiciones distintas e, incluso, aparentemente irreconciliables. Los filósofos pragmatistas frecuentemente ofrecen perspectivas que, claramente, podrían aparecer como slogan opuesto al que defienden otros de sus pares que también se llaman a sí mismos pragmatistas. Pragmatistas como Richard Rorty, por ejemplo, creen que el falibilismo nos prohibe aceptar que la verdad pueda ser la meta de la investigación. Rorty se queja de la «metodolatría» de Peirce y propone avanzar una teoría libre de compromisos metafísicos como los de las teorías sobre la verdad. Contra esta opinión, otros pragmatistas seguidores de Peirce, tales como Cheryl Misak y Christopher Hookway, ofrecen 
In this paper, I aim to ponder Misak's efforts and to further carry them towards a more substantive view of realism that is needed to achieve what Peirce called «the method of science» for the settlement of beliefs.

Keywords: Inquiry, Misak, Peirce, Pragmatism, Truth. una lectura del sentido en que la verdad puede ser la meta de la investigación y en cómo la creencia es racionalmente establecida. En este ensayo, ofrezco una lectura de los esfuerzos de Misak con el propósito adicional de dialogar con sus ideas con miras a establecer la necesidad de una perspectiva más sustantiva realista que es necesaria para conquistar lo que Peirce llamó «el método de la ciencia» para el establecimiento de las creencias.

Palabras clave: investigación, Misak, Peirce, pragmatismo, verdad. 
A pragmatic clarification of Truth

A common view of certain philosophical circles that lean towards relativism holds that theories of truth cannot engage with a naive form of realism, like the one defended, they claim, by the doctrines of truth, understood either as correspondence or coherence. There is a huge amount of literature on the topic and the debates usually confront very serious objections. Many interpreters considered pragmatic doctrines of truth as spurious and quickly dismissed them as inconsistent. Those readers suppose that pragmatists write either from the correspondentist point of view or from a coherentist stance, when they state on truth.

I believe neither of the classical pragmatists adopted the alleged dichotomy that opposes coherentist and correspondentist accounts: indeed, neither Peirce nor James intended to offer an account of the «definition» of truth; they were rather concerned with a «pragmatic clarification of truth» and the things at stake in that clarification are not definitional aspects of truth, but the consequences of our understanding of truth within the context of the rational interpretation of inquiry in action. According to this, the definitional approach with regards to truth must be understood through the norms of rational and self-controlled inquiry, and this circumstance must impinge in the definitional aspects, and not the other way around.

However, common sense considerations about truth ought not to be considered far away from the pragmatic ones. Consider, thus, when inquiry is carried out: we would never knowingly rest in a conclusion we believe as false. Inquiry takes some common sense considerations for granted, but there are many aspects of common sense that might not always be accepted as rational. Inquiry is, thus, a higher concept that engages with a goal-directed activity carried rationally.

There is a sense, though, in which we might have to deny that truth is the aim of inquiry: for example, if we adopt a minimalist 
theory of truth, the concept of truth is just a platitude for what we already believe: saying that I believe that ' $\mathrm{p}$ ' is true is nothing more than saying that I believe 'p' and then saying that the aim of my inquiry is to believe something that I already believe; therefore, it cannot be an end.

A strand of neo-pragmatists that include Richard Rorty think that is better to endorse a weaker goal. Perhaps it will be about enough if we follow certain norms for thinking rationally and, then, only adopt some conditions for warranted assertions. Those views, however, come across as, conceptually, very thin, because they do not actually tell us when an inquiry is satisfied and when it ought to stop-for example, it is the case of sciences, where we know that some answer is accepted as satisfactory because our practical goal is a pattern of satisfactory explanations for a given problem that count as an acceptable solution.

Peirce's pragmatism somehow accepted that truth cannot be the end of inquiry. He provided us of a theory of the settlement of belief which he christened as «the method of science». In Peirce's theory, truth is equivalent to a state of settlement of a belief, but he never implies that such settlement has to be a permanent state. However, Pierce's method is itself a pragmatic clarification of truth for it thinks of truth as the gravitational center around which rationally settled beliefs gravitate and that towards which they tend to. This will be a key concept henceforth: rather than a consensus on what is believed to be the truth, then, stands the «convergence» towards truth, accordingly, i.e., the settlement of a goal-directed inquiry.

Cheryl Misak explains us that the pragmatic Peircean conception of truth must involve an account of how can beliefs turn out «indefeasible» or «superassertible» (to use the equivalent concept popularized by Crispin Wright). The concept of an indefeasible belief is a relevant one, but cannot be properly understood outside what Peirce recognized as the realism that pragmatism presupposes. We will come to reach this problem further below. But first let us delve on those considerations mentioned above in the details of the account provided by Cheryl Misak. 
Misak on Truth as the Aim of Inquiry

In Truth and the End of Inquiry (Misak, 2004), Cheryl Misak provides a Peircean account of truth. She endeavors in the rather onerous task of locating a pragmatist account of truth in Peirce's body of doctrines. She means to accomplish an account of objectivity capable of overcoming Davidson's objections and criticisms to objectivity as the grounds for truth, amongst other concerns. This sort of objectivity will involve subjunctive conditionals of the form: «If you were to do $x$, then $y$ would result». She concurs with Peirce at thinking that it is correct to say that a true hypothesis is one that would be believed at the end of inquiry.

However, the core of Misak's Peircean account - which is given in the two famous papers from the series Illustrations on the Logic of Science: "How to Make our Ideas Clear"(1878) and "The Fixation of Belief" (1877) - is that the views included in those papers were held unaltered by Peirce over the years, ever since he formulated them, in spite of Peirce's own further and significant philosophical development. I am going to assume the same claim, but with a pinch of salt.

I propose that, even though Peirce never changed his views as contained in those materials, he nonetheless changed the focus by which they should be understood. Substantively, indeed. I take, for example, his «Scholastic Realism» as the view that represents his mature thought. This view distanced Peirce from his early views in important issues, actually.

I will offer more argumentative ammunition on this at the last section of this paper. However, for now, it matters to highlight what I consider to be a very remarkable insight in Misak's interpretation of Peirce: i.e., the way she understands the conditional sentence that expresses the pragmatic clarification of Truth in her Peircean account. Consider a definitional or constitutive theory of Truth. It will offer, primarily, a biconditional of the following sort:

Given that $H$ is the result of an inquiry, $H$ is true if and only if inquiry was pursued as far as it could fruitfully go; then, $H$ would be believed to be true. 
This formulation seems to reflect the Peircean account, but weakly so, since assumes that $H$ is a stable state of belief. The risk of such formulation is an identification such as $H \leftrightarrow T$, where $H$ is a finite premise and $T$ a consequence that can be formulated in a particular proposition and that fully reflects truth.

Misak interprets that the latter would certainly be enough for a basic definition of truth, though a family of objections might be raised to other uses of the term «Truth». For example, how can the latter sentence account for coherence or the problem that there are facts for which we have no possible access to (for example, how many times Winston Churchill sneezed in 1949)? Thusly, she thinks that Peirce provides us of a relevant case of conceiving the consequences of the truth of a hypothesis:

It is a consequence of $« H$ is true» that, if inquiry were to be pursued, $H$ would be believed.

This conditional does not move from inquiry to truth, as the definitional (constitutive) version does, but from truth to the deliverances of inquiry. This inversion aims to match with our uses of the concept in a better way: it does not force us to say that truth is an individual proposition. This has a liberating effect: we would want to call true a family of propositions that direct us to the settlement of belief, instead of a fixed and permanent proposition. In addition, Peirce thinks that there is no more to truth that what inquiry would offer us to settle upon. Then, saying that $H$ is true cannot mean anything transcendental or permanently veiled to continuous and selfcontrolled inquiry. Inquiry will give us beliefs that we would want to call true.

Questions on objectivity, bivalence and Truth

Many objections directed against theories of truth come from a property of truth called «bivalence»: a proposition/belief cannot be both false and true. But, what if it happens to be neither of those? 
What if it is permanently indeterminate, because its truth cannot be corroborated or settled?

Let me bring the case of the so-called «buried facts» forward again: there is no way to know, according to Misak, how many Tyrannosaurus Rex there were about in the Jurassic period. ${ }^{1}$ Thus, shall we rather give up theories of truth altogether, due to those buried and unachievable facts for which the evidence is not available for us anymore (no matter how good enough and well enough we inquire into it)? I think we certainly should accept the fact that absolute bivalence cannot be the case. This matter, however, does not affect, as far as I can see, the important and, as Misak calls it, «uncontentious» claim about Truth and the inquirer: the philosopher and the inquirer ought to adopt the «method of science» not because there is a determinate answer to every possible question, but because the structure of reality seems to offer us convergence: a convergence into fewer answers to multiple questions that are raised by the irritation that genuine doubts impinge upon us.

Thus, for instance, it will be rather idle to try to find out evidence for the question that the world was created five minutes ago (as Bertrand Russell creatively put it), because there is hardly anything that counts as evidence for that. Genuine doubts are settled by beliefs that turn out to be indefeasible, i.e., that gravitate and point to relevant and continuous evidence. Peirce thought that artificial and unauthentic doubts crop up from nominalist scruples. Nominalists only accept some items as real, dumping others apart and, thereby, they open the door to all sorts of skepticisms. The pragmatic conception of truth, that the inquirer ought to adopt, according to Peirce, is restrained to: "Truth as can and ought to be used as a guide for conduct” (1913, MS 684: 11).

Misak, agreeing with the above, reckons that this is a case of the conditional description of truth that goes from inquiry to truth. She remarks the same issue:

1 A paleontologist has pointed out to me that the Tyranossaurus Rex is not precisely fixed in the Jurasic period of the Mesozoic era, but even well within the Cretaceous period, which adds to the point of our example some further interest. 
Truth is the property of those beliefs that would encounter no recalcitrant experience, broadly construed. Truth is the property of those beliefs that a sufficiently pursued experience-constrained inquiry would turn up. And (T-I): we must assume that if a hypothesis is true, then if we were to inquire about it, eventually something would impinge upon us to convince us of its truth (Misak 2004: 160).

Misak holds that there are many virtues for an account of truth so construed: Her account of Peircean truth: 1) provides a rational context for inquiry to proceed, 2) makes sense of the practice of inquiry as the search for truth, and 3) provides and justifies methodology. Hence, all things being equal, whatever the method of inference (induction, deduction and abduction) we pick our inferences on, we can nonetheless rely that the method of science applied will lead us to converge with the structure of experience broadly constructed.

\section{Fallibilism, Inquiry and Realism}

Richard Rorty thought that there are some pragmatic arguments that can prevent us of believing that truth is the aim of inquiry: he offers a slogan that states:

You can only work for what you could recognize (Rorty, 2000: 4).

This means that if I want to carry out any kind of investigation, let us say, for catching a train going from York to Edinborough, I need to be able to identify the aims of what I have to do in order to not miss the transportation. However, that is somehow far from a definitive truth, because sometimes the means to obtain my goal might differ: I could use the board at the railway station, I could browse time departures online, I could ask a friend and so forth. It will be misled to say that a particular mean is truer than another. Means are just good relatively to what I need. 
Furthermore, it might happen that whatever we consider true as of now, eventually turns out to be false, as it has effectively happened numerous times in the history of knowledge, or rather in the history of fallible long-held beliefs. A classical example of this could be the shift from modern Newtonian physics to the contemporary complex not-unified physics that is partly governed by General Relativity for the macro-universe and Quantum Mechanics for the micro-universe. In such situation (as of today) there is no shared truth between these two governing theories. Rorty's challenge can be summarized as follows: if fallibilism is the case, truth cannot be the aim of inquiry.

Rorty's challenge might be better understood by revisiting Davidson's thoughts on the consequences of fallibilism. Davidson (2005) argues that if fallibilism is the case, truth cannot be the end of inquiry, as the end of inquiry is objective and objectivity is problematic (to say the least) because: a) truths do not come with a mark like the date in the corner of a photograph that distinguishes them from falsehoods, b) It also states that however long and well we inquire, we shall be left with fallible beliefs, and c) We will never know for certain which of our beliefs are true.

Peirce was not far from understanding the challenge posted by Rorty. As Chris Hookway tells us, Peirce actually provided a theory of fallibilism long before the better-known theories of Popper about fallibility in science (2007: 21). Peirce was sure that we cannot be absolutely certain of the truth of a belief; no matter how settled the belief appears to be.

Still, he does not reject truth altogether. Misak seems to affirm that Peirce's move stands the challenge of understanding truth as an aim of inquiry because there are some beliefs that turn out to be indefeasible, and we are better off if we adopt them, unless we have real grounds to doubt them. Why is this conduct better than rejecting truth altogether? The answer is quite clear: preserving a minimal account of truth provides us of an account of the norms that should govern inquiry. These norms offer us an explanation of the means to find pragmatic consequences. Explanations of this kind will naturally be a matter, of course, if inquiry were fruitfully taken. 
This strategy proves much better than the relativistic one with regards to their approach to truth: it provides us with a regulative hope about inquiry and its aims. We call beliefs «true» when we are epistemically warranted about their settlement, albeit they can only be approximately true.

Fallibilism, therefore, rather than a fatal strike to the concept of truth, is a way of being epistemically aware of error-sensitiveness and refinement of our best theories. I find very enlightening the mentioned pragmatistic move, though I do not think it is enough to achieve a minimal account of truth. As Peirce acknowledged, if we want to aim for the best explanation of why there are regulative patterns in all sorts of inquiries, then we still need to accept a first and foremost important hypothesis that explains why there are pervasive patterns in the first place: he called this the «hypothesis of reality».

Indeed, Peirce provided an account of truth by offering an account of reality. If reality impinges upon our inquiries in a pervasive and regulated way it will be plausible to accept that certain items considered by our inquiries have to be held as real. Realism, thence, is in the summit of the theory: one cannot be wholly pragmatist without finding reasonable the expectations of the subjective conditionals of inquiry and only the hypothesis of reality makes them wholly reasonable and a matter of course.

Pragmatists like Andrew Reynolds and myself propose that the statistical approximation to the ideal limit that the pragmatist conception of truth conveys is due to a realism that Peirce called Synechism. Synechism is the hypothesis that there is real continuity operative in nature. The continuity of habits gives a metaphysical explanation of regularity. This account cannot be fully introduced here, but it gives a good clue as to how Peirce wanted the matter to be reconsidered.

Consider, finally, the case of the inquiry that eventually became the theory of gases developed by Clausius, Maxwell and Boltzmann (Garber, 1970). Such a theory is only possible as long as it is able to avoid accounting for each of the particles in a confined given gas, in order to focus the attention in the behavior of the gas as a continuum with different patterns. The behavior of these patterns provides 
statistical information and different proportional relations of idealized variables. In the same wise, the realism proposed by Peircean pragmatism is a realism of habits understood as pervasive regularities that become the content of what we can, afterwards, call, laws of nature, comfortably.

Now, the way in which Peirce dealt with this problem is present in: his category «realism», his objective idealism and his theory of signs. Each of these doctrines build up towards a substantive theory of reality that ultimately will provide us of a pragmatic account of truth. Here, I will stop, but not without mentioning these elements of his architectonic system or without stressing the importance of them to account for truth as the aim of inquiry. Misak's account might not fully tackle all the issues related to truth. We need more substantive elements to correlate reality and inquiry. Nonetheless, she provided us of a fresh start, free of scruples in relation to truth. After all, for a pragmatist and for pragmatic purposes, to be «methodologically realist» means nothing else but being a «realist». Peirce would even add that it means to be an «Extreme Scholastic Realist».

\section{References}

Davidson, D. (2005). Truth, Language and History. Oxford: At Clarendon Press.

Garber, E.W. (1970). “Clausius and Maxwell's Kinetic Theory of Gases”. Historical Studies in the Physical Sciences 2: 299-319.

Hookway, C. (1985). Peirce. London: Routledge.

Hookway, C. (2002). Truth, Rationality and Pragmatism. Themes from Peirce. Oxford: Oxford University Press.

Hookway, C. (2007). "The inaugural address: Fallibilism and the aim of Inquiry”. Aristotelian Society Supplementary 81 (1): 1-22.

Misak, C. (1987). "Peirce, Levi and the Aims of Inquiry". Philosophy of Science 54 (2).

Misak, C. (2004). Truth and the End of Inquiry. Oxford: Oxford University Press. 
Peirce, C.S. (1877/1878). "The Fixation of Belief”; "How to Make our Ideas Clear". The Essential Peirce,Vol. I. N. Houser, C. Kloesel, eds. Bloomington: Indiana University Press.

Peirce, C.S. (MS). Microfilm: The Charles Sanders Peirce Papers. Cambridge, Mass.

Rorty, R. (2000). “Universality and Truth”. Brandom, R. Rorty and his Critics. Oxford: Blackwell. 